\title{
Causes and circumstances of maritime casualties and crew fatalities in British merchant shipping since 1925
}

\author{
Stephen E. Roberts ${ }^{1}$, Tim Carter ${ }^{2}$ \\ ${ }^{1}$ Medical School, Swansea University, Swansea, United Kingdom \\ ${ }^{2}$ Department of Occupational Medicine, Norwegian Centre for Maritime and Diving Medicine, \\ Haukeland University Hospital, Bergen, Norway
}

\begin{abstract}
Background: To determine the causes and circumstances of vessel accidents that led to fatalities in British merchant shipping since 1925, and among British seafarers who were employed in non-United Kingdom shipping since 1985. Secondly, to establish trends in vessel accidents and crew fatalities, and associations with type of casualty and location, type of ship, cargo carried and season.

Materials and methods: Reviews of annual mortality returns, marine accident investigation reports, death inquiry files, Lloyd's casualty returns, online newspapers, shipwreck websites and other searches over the period from 1925 to 2017 but excluding 1939 to 1946.

Results: The study identified 362 ship accidents in British shipping that led to 2760 crew and 605 passenger fatalities. There have been large reductions in both ship casualty and crew fatality rates, which have been greatest for vessels that were stranded, wrecked or foundered, particularly small coastal trading cargo ships. Reductions since the 1980s have coincided with proportionate increases in ship accidents and consequential crew fatalities among British seafarers employed in 'open register' shipping. Strong seasonal and geographical patterns show that most fatalities through foundering or wrecking occurred during winter months around Europe.

Conclusions: Reductions in ship accidents and crew fatalities reflect major developments and improvements in ship navigational aids, improvements in rescue services and ship designs, and reductions in the volume of small coastal trading ships. Some disasters in 'open registry' shipping occurred in controversial circumstances, suggesting that substandard shipping has been flagged out or that lower cost but less competent crews have been employed.
\end{abstract}

(Int Marit Health 2018; 69, 2: 99-109)

Key words: maritime casualties, fatalities, seafarers, British shipping

\section{INTRODUCTION}

Historically, casualties (or accidents) to ships have accounted for high proportions of all deaths among merchant seafarers at sea [1-3], although this appears to have fallen in world shipping in recent decades $[4,5]$. However, little has been reported from population based studies of long term trends in ship casualties and crew fatalities, while evidence on links between the causes of shipping casualties and subsequent crew fatalities in merchant shipping are lacking.
The main aims of this study were, first, to determine the causes and circumstances of all vessel accidents that led to fatalities in British merchant shipping over the 92-year period from 1925 to 2017 (excluding the years from 1939 to 1946), as well as among British seafarers who were employed in non-United Kingdom (UK) shipping since 1985. Secondly, to establish trends in the causes and circumstances of the vessel accidents and fatalities overall and in relation to factors including the type of casualty and location, type of ship, cargo, location and season. 


\section{MATERIALS AND METHODS}

Annual returns on mortality among merchant seamen employed in British merchant ships have been published from the mid-19 ${ }^{\text {th }}$ Century to 1988 , and subsequently returns covering fatal accidents have been published annually by the Marine Accident Investigation Branch. Information on the numbers of fatalities from ship accidents in the British fleet and the populations of seafarers employed were therefore obtained for the study period from 1925 to 2017 from these annual mortality returns and from surveys conducted by the Maritime and Coastguard Agency. The returns were published variously by the Board of Trade, the Ministry of Transport, the Department of Trade and Industry, the Department of Industry, the Department of Trade, the Department of Transport and the Marine Accident Investigation Branch [6-11].

The annual returns provide basic numerical summaries and do not include detailed information on the causes and circumstances of ship casualties and crew fatalities, while no other single information source provides coverage of all vessel casualties over the whole study period. Therefore, to establish the causes and circumstances of all vessel casualties, information was compiled extensively from a range of different sources. These were, firstly, official accident investigation reports, conducted by the Marine Accident Investigation Branch since 1989 [10] and in previous years since 1925, variously by the Board of Trade, the Ministry of Transport, the Department of Trade and Industry etc. [6-9].

As many vessel casualties were not subject to official investigation before the MAIB was established in 1989, additional information sources used include Lloyd's Register casualty returns (available from 1963 to 2010) [4, 12], Lloyd's Maritime Information Services casualty details (from 1963 to 1996) [13], and death inquiry files and death registers held at the Registry of Shipping and Seamen (from 1976). Other sources of information, covering all study years, involved extensive searches of the wrecksite.eu website [14], the British Newspapers Archive [15], information provided by members of the Ships Nostalgia website, lifeboat websites and various other searches. For verification, details of the vessel accidents and crew fatalities were cross referenced across different information sources and with coroner's inquisitions. Cases were excluded where there were doubts about the credibility of the details or doubts about fulfilling the study inclusion criteria.

The study included all identified vessel accidents and subsequent fatalities in merchant or trading ships or vessels of any tonnage that were registered in a British port. These include all types of steam and motor cargo-carrying ships along with passenger liners and ferries, tugs, dredgers, river barges, and all types of merchant sailing vessels including barques, schooners and ketches. The study excluded all vessel accidents that affected fishing vessels, pleasure boats, rescue lifeboats, pilot launches and harbour craft. It also excluded all crew fatalities in merchant ships that arose from personal accidents rather than from accidents or damage to the ship, for example, through falls on board, crew being washed overboard without major damages to the ship or though off-duty accidents involving ships' boats when seamen went ashore or back to the ship. The study excluded the years from 1939 and 1946 as frequent vessel disappearances during these years are often difficult to distinguish from war casualties. The study also excluded all vessel incidents that were confirmed to have been casualties during any other conflicts, but included several casualties in years after conflicts had ended, which were caused - or were probably caused - by ships' striking uncleared mines.

Ship accidents or casualties have been subdivided into five categories. These are, firstly, ships that foundered, capsized or disappeared and were usually presumed to have foundered. Secondly, collisions which include contacts and girtings during tug operations. Third, ships that grounded, were wrecked or stranded, typically on rocks, beaches and harbour walls during severe weather. Fourth, fires and explosions; and fifth, other casualties which include major structural or mechanical damages (often storm related) or vessels that struck mines. In the analysis, we have categorised ship disappearances along with foundering and capsize as they are usually sudden and considered to be foundering or capsize through severe weather and/or sudden structural failure. However, it is likely that at least some may have been caused by other types of sudden casualty, for example, catastrophic explosions involving hazardous cargoes or unreported collisions or wrecking.

The British merchant fleet declined heavily during the 1980s as many cargo-carrying ships were re-registered with 'open register' flags. Therefore, as a supplementary analysis, the study additionally investigated and assessed vessel accidents and fatalities among UK seafarers who were employed on board open register and other non-UK registered ships from 1985 up to the end of the study in 2017.

Ship casualties and subsequent crew fatalities have been investigated in relation to several factors, including the type of ship and the cargo carried, the geographical location of the casualty and the time period in which the casualty occurred. The main study outcome measures were ship casualties, fatalities from ship casualties and mortality rates per 100,000 population of seafarers, calculated using the numbers of fatalities as numerators and the populations at risk as denominators. Other methods of analysis include time trend analysis with mortality rates smoothed using 3 year moving averages.

\section{RESULTS}

Over the entire study period from 1925 to 2017, the information sources identified a total of 362 vessel casu- 


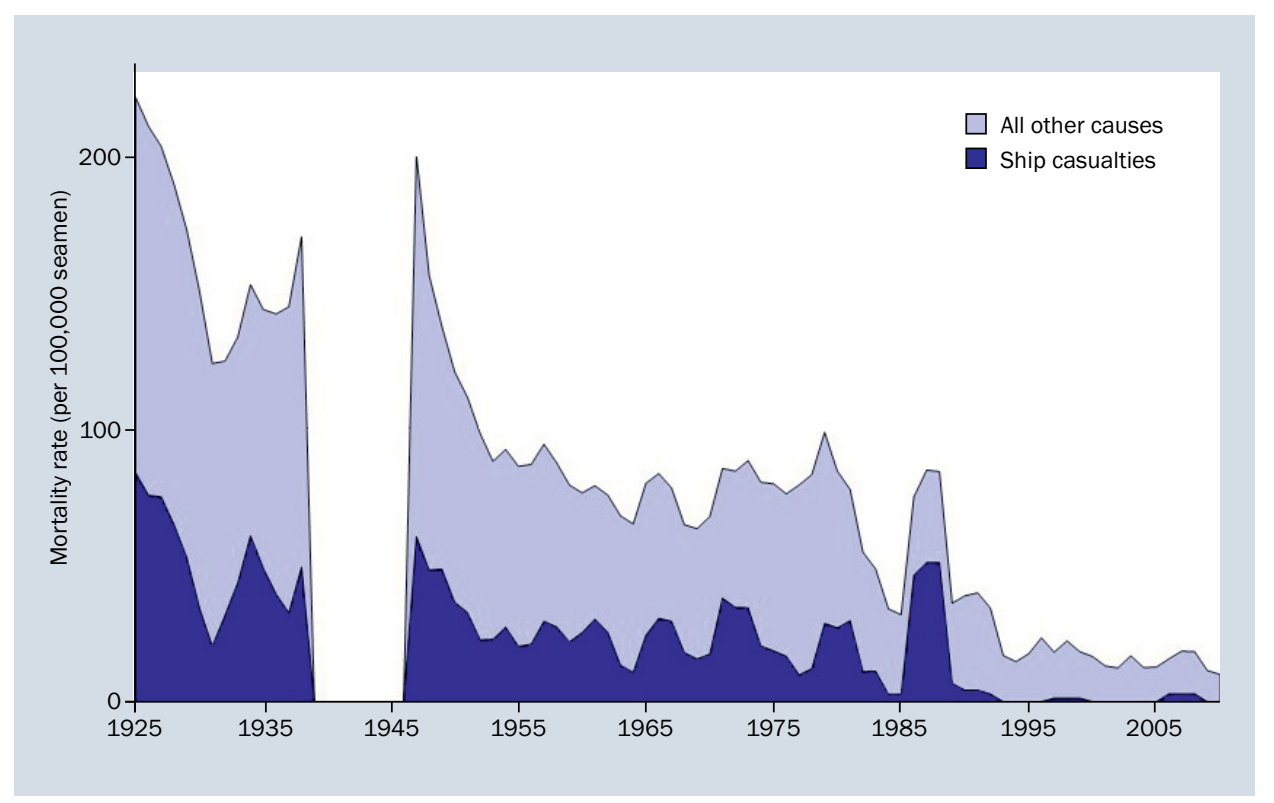

Figure 1. Trends in mortality from ship accidents and from all other causes in British merchant shipping, 1925 to 2010. Note: Mortality rates are smoothed using 3 year moving averages to illustrate mortality trend patterns

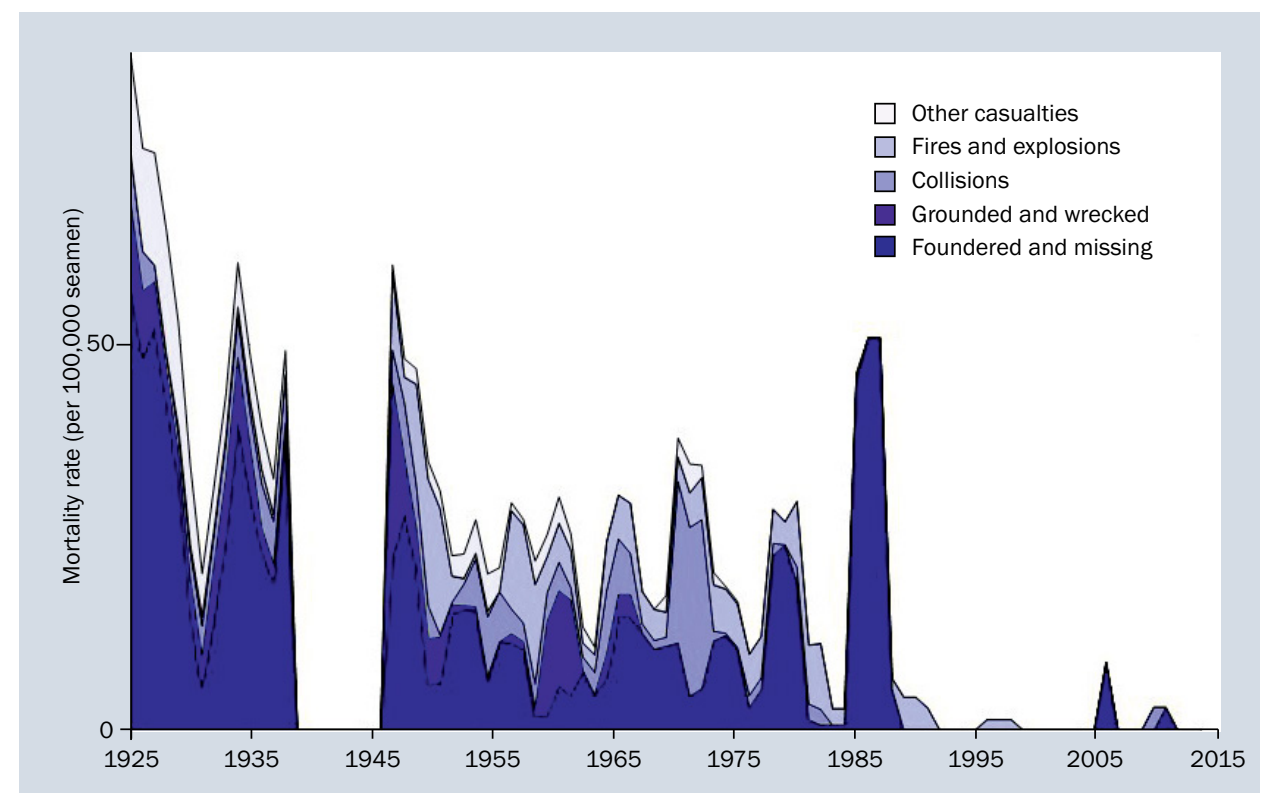

Figure 2. Trends in mortality from ship accidents according to the type of casualty in British merchant shipping, 1925 to 2017. Note: Mortality rates are smoothed using 3 year moving averages to illustrate mortality trend patterns

alties in British shipping that fulfilled the study inclusion and exclusion criteria, with a total of 2760 crew fatalities. 605 passengers were also lost through these shipping casualties.

\section{TRENDS IN MORTALITY FROM SHIP CASUALTIES}

There has been a sharp decline over time in mortality arising from ship casualties in British shipping over the study period since 1925, which reflects a comparable reduction in seafarer mortality overall (Fig. 1). Heavy loss of life from vessel casualties in particular years evidently led to annual peaks in crew mortality overall. Vessel casualties have accounted for $32 \%$ of all fatalities since 1925 , although this has fallen in more recent years (Fig. 1).

Figure 2 shows that ships foundering accounted for most crew fatalities from vessel accidents throughout the 
study period and that this appears to have proportionately increased in recent years. There has been a sharp reduction since the 1950s in both vessel accidents and crew fatalities through ships being wrecked or stranded (Figs. 1, 2), but an increase during the 1950s and 1960s in mortality from fires and explosions, linked partly to the expansion of bulk oil and chemical transport at this time.

\section{CAUSES AND CIRCUMSTANCES OF SHIP CASUALTIES WITH FATALITIES}

Table 1 provides brief details of all vessel casualties in British shipping since 1970 in which crew were lost. This shows a decline over time in both the volume of ship disasters and also crew mortality. By the 1970 s and early 1980 s, much of the mortality refers, firstly, to small general cargo or other dry cargo coastal trading ships, often ageing, which foundered, usually in bad weather, in the waters around Northern Europe. Secondly, fires in the accommodation areas of various types of cargo ships and also isolated disasters that caused heavy loss of life. These include the capsize of the passenger ferry MV Herald of Free Enterprise which had departed Zeebrugge, Belgium with its bow doors left open (38 crew and 155 passengers lost, 1987) [16], the disappearance of the bulk carrier MV Derbyshire when carrying iron ore during a typhoon off Japan (44 crew and 2 passengers, 1980) [17], and a collision involving the refrigerated cargo steamship SS Royston Grange and a Liberian registered oil tanker, which was overdue and had entered the River Plate with questionable draft (64 crew and $10 \mathrm{pa-}$ ssengers, 1972) [18].

In the most recent 30 years since, there have been 7 ship casualties with loss of life (Table 1). Four have involved tugs, either collisions or capsize (6 seafarers lost). The others refer to the foundering of a dredger during gales ( 4 crew lost), an explosion and fire in the pump room of an oil tanker (2 lost) and a fire in the accommodation area of a general cargo ship (1 lost).

More than twice as many ship accidents involving loss of life to British seafarers have occurred in 'open register' and other non-UK flags (20) than in British shipping since 1985 (9; Table 2). However, as few British seafarers are typically employed in a non-UK ship, the total fatalities in non UK shipping (42) are lower than in British shipping (55) during the same period.

The vessel casualties in non-UK ships include several small general cargo ships that foundered when carrying cargoes of ores and metals around Europe. Some disasters, involving ships registered under flag administrations such as Belize, Liberia, Panama and Gibraltar, occurred in notorious circumstances that generated considerable concern. For example, one involved the Liberian-registered chemical tanker MV Maasgusar (1989) which was gutted without any trace of the 4 British and 19 Filipino crew on board, after they had been tasked with carrying a cargo of 8 different chemicals across the North Pacific [13]. The wreck was subsequently ablaze for another 7 weeks and 100 miles of ocean crossed before finally disappearing. The ships' owners had no commercial responsibility for the ship, having bareboat chartered the vessel to an overseas affiliate, who had then subcontracted the ship management and time chartering to two other separate overseas organisations [13]. A second involved the management of a Panamanian-registered general cargo ship, MV Marine (1989), who recruited most of the crew either unqualified and untrained or, for the ship's engineering department, from a public labour exchange, shortly before it disappeared without trace on a short voyage from Liverpool to Northern Spain [19]. A third disaster concerns the Belize-registered, 'Bahamas-owned' general cargo ship MV Rema (1998) that foundered through severe leakage to a hold so quickly after leaving the Scottish port of Berwick that all crew on board were drowned before they had sufficient time to react [20].

\section{TYPE OF SHIP AND CARGO}

There have been sharp reductions over time in vessel casualties (that led to fatalities) in most sectors of merchant shipping, although this is less evident for tugs and dredgers, while there was a peak in fatalities from fires and explosions in oil tankers during the 1950s and 1960s (Table 2). Apart from sail shipping which had diminished by the 1920s, the largest reductions are evident for general cargo ships that foundered when carrying coal, grain or stone cargoes or were in ballast and for river barges, as well as for ships that were stranded or wrecked.

Of 25 coastal general or dry cargo ships (< 2500 gross tonnage) that have foundered or capsized (with loss of life) over the last 70 years (total of 155 crew fatalities), shifting of cargo was identified as a major cause or contributory factor in the majority of cases (15). Weather and sea state conditions, typically gales or storms, were also major factors in almost all of these cases. The cargoes that shifted were coal (6), iron or lead (3), stone chips or chippings (3), wheat or grain (2) and timber (1). The main causes of the other 12 coaster casualties largely involved hatch cover failures, other leakages, unstable or unseaworthy ships and extreme weather conditions. Only 2 cases of cargo shifts were identified from inquiry reports as having caused crew losses to larger deep sea trading ships.

Of 363 fatalities from fires and explosions during the last 70 years, 108 occurred among the crews of tankers and most broke out in engine rooms or machinery spaces (45) or in cargo tanks (42) followed by accommodation areas (14). Tanker fatalities in engine rooms or machinery spaces were mostly in port during cargo loading or discharge 
Table 1. Details of all vessel accidents that led to fatalities in British merchant shipping, 1970-2017

\begin{tabular}{|c|c|c|c|c|}
\hline Year & Type of ship & $\begin{array}{l}\text { Gross ton- } \\
\text { nage; age } \\
\text { of ship }\end{array}$ & $\begin{array}{l}\text { Seafarers } \\
\text { (and passen- } \\
\text { gers) lost }\end{array}$ & Details of the maritime casualty \\
\hline 2012 & MV tug & $\mathrm{nk} ; \mathrm{nk}$ & 1 & $\begin{array}{l}\text { Capsized and foundered in the English Channel off the Lizard Point, } \\
\text { when on voyage from Northern Spain to the UK. Two crew rescued. }\end{array}$ \\
\hline 2011 & MV tug & $92 ; 47$ & 1 & $\begin{array}{l}\text { Collision with a crane barge along the River Thames, capsized and } \\
\text { foundered. Two crew survived }\end{array}$ \\
\hline 2007 & MV tug & $486 ; 26$ & 3 & $\begin{array}{l}\text { Capsized after colliding with a bulk carrier it was assisting in dense } \\
\text { fog along the River Clyde. One other crew injured. }\end{array}$ \\
\hline 1998 & MV tug & $38 ; 21$ & 1 & Girted and capsized at Milford Haven. One crew rescued. \\
\hline 1991 & MV tanker & 11,$898 ; 20$ & 2 & $\begin{array}{l}\text { Explosion in the pump room when discharging the cargo of naphtha } \\
\text { and petrol at dock in Fawley, from Amsterdam. }\end{array}$ \\
\hline 1990 & MV general cargo ship & $424 ; 20$ & 1 & Accommodation area gutted by a fire when in port at Queenborough. \\
\hline 1988 & MV dredger & $1503 ; 20$ & 4 & $\begin{array}{l}\text { Broke in two and foundered during a gale in the English Channel } \\
\text { off Belgium. Six crew rescued. }\end{array}$ \\
\hline 1987 & MV passenger ferry & $7951 ; 6$ & $38(155)$ & $\begin{array}{l}\text { Capsized soon after departing Zeebrugge, Belgium for Dover with } \\
\text { the bow doors left open. } 155 \text { passengers lost. }\end{array}$ \\
\hline 1985 & MV tug & $64 ; 22$ & 4 & Foundered after colliding with a general cargo ship, River Thames. \\
\hline 1985 & MV bulk carrier & 91,$178 ; 10$ & 1 & Fire in the accommodation area when docked in Taiwan. \\
\hline 1984 & MV tanker & $2886 ; 14$ & 2 & Explosions in the pump room when at dock in Milford Haven. \\
\hline 1984 & MV tug & $300 ; 8$ & 1 & $\begin{array}{l}\text { Capsized and foundered during a gale in the English Channel, } \\
\text { when on passage from Rosyth to the South Atlantic. }\end{array}$ \\
\hline 1982 & MV general cargo ship & $8138 ; 18$ & 5 & $\begin{array}{l}\text { Foundered during heavy weather off Cornwall, from Casablanca to } \\
\text { Whitehaven with a phosphate cargo. Six crew rescued. }\end{array}$ \\
\hline 1982 & MV passenger ferry & $4263 ; 6$ & $4(2)$ & $\begin{array}{l}\text { Collided with another ferry and foundered during heavy weather in } \\
\text { the North Sea, from Felixstowe to Rotterdam. Two passengers lost. }\end{array}$ \\
\hline 1982 & MV tanker & 33,$239 ; 4$ & 10 & Fire in the accommodation area in the Caribbean Sea. \\
\hline 1982 & MV tanker & 140,$264 ; 16$ & 3 & Fire in the engine room when anchored off Singapore. \\
\hline 1981 & MV general cargo ship & $8138 ; 11$ & 4 & Machinery failure when in port in Manfredonia, Italy. \\
\hline 1981 & MV general cargo ship & $1777 ; 29$ & 4 & $\begin{array}{l}\text { Foundered after the cargo of scrap iron shifted in heavy weather in } \\
\text { the Irish Sea, from Belfast to Bilbao. Eight crew rescued. }\end{array}$ \\
\hline 1981 & MV general cargo ship & $647 ; 23$ & 1 & $\begin{array}{l}\text { Foundered after listing during a storm in the English Channel, from } \\
\text { Bordeaux to Teignmouth with a cargo of maize. Five rescued. }\end{array}$ \\
\hline 1981 & MV tanker & $1594 ; 10$ & 1 & Explosion and fire at dock in Milford Haven with a gasoline cargo. \\
\hline 1980 & MV powder carrier & $1232 ; 12$ & 1 & $\begin{array}{l}\text { Explosion in the North Sea, when on voyage from The Netherlands to } \\
\text { Howdendyke with a cargo of glucose starch. }\end{array}$ \\
\hline 1980 & MV general cargo ship & 1599; 7 & 1 & $\begin{array}{l}\text { Fire in a hold in port at Cherbourg, having arrived from Swansea with } \\
\text { a cargo of anthracite dust. }\end{array}$ \\
\hline 1980 & MV chemical tanker & $4062 ; 10$ & 1 & Fire in the engine room, when in port at Annaba, Algeria. \\
\hline 1980 & MV bulk carrier & 91,$655 ; 3$ & $42(2)$ & $\begin{array}{l}\text { Foundered with all crew and two passengers following hatch cover } \\
\text { failure amid a severe typhoon in the north west Pacific off Japan. On } \\
\text { voyage from Canada to Kawasaki, Japan, with a cargo of iron ore. }\end{array}$ \\
\hline 1979 & MV general cargo ship & $1028 ; 20$ & 12 & $\begin{array}{l}\text { Capsized in the English Channel when, reportedly, attempting to avoid } \\
\text { collision with an oil tanker. Two crew rescued. }\end{array}$ \\
\hline 1979 & MV tanker & 499; 14 & 4 & Explosion and fire on deck during cargo unloading in Abu Dhabi. \\
\hline 1978 & MV RFA supply ship & $4823 ; 16$ & 1 & Fire in the accommodation area in the Mediterranean Sea off Spain. \\
\hline 1978 & MV general cargo ship & 496; 4 & 4 & $\begin{array}{l}\text { Capsized after a collision with a general cargo ship along the River } \\
\text { Seine. One of the crew survived. }\end{array}$ \\
\hline 1978 & MV general cargo ship & $5973 ; 11$ & 2 & Fire in the accommodation area at dock in Cardiff. \\
\hline 1977 & MV tanker & 18,$493 ; 0$ & 1 & Explosion in the engine room in the North Atlantic. \\
\hline
\end{tabular}


Table 1 cont. Details of all vessel accidents that led to fatalities in British merchant shipping, 1970-2017

\begin{tabular}{|c|c|c|c|c|}
\hline Year & Type of ship & $\begin{array}{l}\text { Gross ton- } \\
\text { nage; age } \\
\text { of ship }\end{array}$ & $\begin{array}{l}\text { Seafarers } \\
\text { (and passen- } \\
\text { gers) lost }\end{array}$ & Details of the maritime casualty \\
\hline 1977 & MV RoRo cargo & 4493; 4 & 1 & $\begin{array}{l}\text { Capsized and foundered in the North Sea after the cargo of containers } \\
\text { and motor vehicles shifted during a gale, on passage from Esbjerg to } \\
\text { Grimsby. } 26 \text { crew and two passengers rescued. }\end{array}$ \\
\hline 1977 & MV drilling ship & $8046 ; 19$ & 1 & Explosion and fire on deck in the Mediterranean Sea. \\
\hline 1976 & MV tanker & 12,$301 ; 17$ & 2 & Fire in the accommodation area in port at Hamburg. \\
\hline 1976 & MV general cargo & $499 ; 15$ & 8 & $\begin{array}{l}\text { Capsized and foundered with all crew after the cargo of wheat } \\
\text { shifted during a gale in the North Sea when sailing from } \\
\text { Brunsbüttel to Leith. }\end{array}$ \\
\hline 1976 & MV bulk carrier & 91,$655 ; 0$ & 2 & $\begin{array}{l}\text { A boiler exploded in the engine room at Flushing, Holland, when } \\
\text { taking bunkers for her maiden voyage. Foundered off Japan } \\
4 \text { years later. }\end{array}$ \\
\hline 1976 & MV bulk carrier & 43,$742 ; 1$ & 1 & Fire in the crew lounge in the Bristol Channel off Port Talbot. \\
\hline 1976 & MV tug & nk; 15 & 1 & $\begin{array}{l}\text { Capsized and foundered off Lowestoft after a collision when } \\
\text { assisting a cargo ship. Three crew rescued. }\end{array}$ \\
\hline 1975 & $\begin{array}{l}\text { MV salvage/offshore } \\
\text { supply ship }\end{array}$ & $314 ; 10$ & 8 & $\begin{array}{l}\text { Foundered after capsize in the Cape of Good Hope when assisting } \\
\text { in loading the anchor and cable aboard a bulk carrier. }\end{array}$ \\
\hline 1975 & MV general cargo & $1092 ; 13$ & 11 & $\begin{array}{l}\text { Capsized and foundered after the cargo of anthracite dust shifted } \\
\text { during a gale off Cornwall, after departing Swansea for Les Sables } \\
\text {-D'olonne. Two crew rescued by the Penlee lifeboat. }\end{array}$ \\
\hline 1975 & MV tanker & $497 ; 7$ & 5 & $\begin{array}{l}\text { Foundered during a gale in the Persian Gulf, from Muscat to } \\
\text { Bahrain in ballast. }\end{array}$ \\
\hline 1974 & MV offshore tug & $669 ; 7$ & 6 & $\begin{array}{l}\text { Capsized and sank during a gale in the Mediterranean off } \\
\text { southern France. }\end{array}$ \\
\hline 1974 & MV general cargo & $471 ; 10$ & 1 & $\begin{array}{l}\text { Flooded and foundered during a storm in the English Channel off } \\
\text { Dorset. }\end{array}$ \\
\hline 1973 & MV general cargo & $195 ; 13$ & 5 & $\begin{array}{l}\text { Capsized and foundered in the Firth of Clyde after the cargo of coal } \\
\text { shifted, travelling from Ayr to Glasgow. One survivor. }\end{array}$ \\
\hline 1973 & MV tanker & 12,$166 ; 15$ & 5 & Collision and fire, later foundered, when entering Hong Kong harbour. \\
\hline 1972 & $\begin{array}{l}\text { SS refrigerated } \\
\text { cargo ship }\end{array}$ & 15,$875 ; 18$ & $64(10)$ & $\begin{array}{l}\text { Explosion and fireball following a collision with a Liberian oil tanker } \\
\text { amid dense fog in the River Plate, bound for London from Montevideo } \\
\text { with a cargo of butter and meat; all people on board lost. }\end{array}$ \\
\hline 1972 & MV general cargo & $635 ; 19$ & 1 & $\begin{array}{l}\text { Foundered after a collision in the North Sea when on route to } \\
\text { London from Rotterdam with a cargo of fertiliser. }\end{array}$ \\
\hline 1972 & MV general cargo & $495 ; 12$ & 4 & $\begin{array}{l}\text { Capsized and foundered after the cargo of lead concentrates } \\
\text { shifted during a gale in the North Sea, travelling from the River } \\
\text { Trent to Ghent. }\end{array}$ \\
\hline 1971 & MV bulk carrier & 66,$057 ; 0$ & 1 & $\begin{array}{l}\text { Explosion in a hold during hold cleaning in the North Atlantic off } \\
\text { Spain. }\end{array}$ \\
\hline 1970 & SS cargo & 15,$875 ; 18$ & 18 & $\begin{array}{l}\text { Foundered after striking a breakwater off Genoa after anchors } \\
\text { dragged during gales. From Novorossiysk with chrome ore, } \\
38 \text { survived. }\end{array}$ \\
\hline 1970 & MV general cargo & $521 ; 10$ & 10 & $\begin{array}{l}\text { Foundered in the North Sea, soon after departing Middlesbrough } \\
\text { for Cork with a cargo of steel plates. Considered unstable. Four } \\
\text { rescued. }\end{array}$ \\
\hline 1970 & MV general cargo & 200; 8 & 2 & $\begin{array}{l}\text { Stranded and wrecked during a gale in the Irish Sea off the Isle } \\
\text { of Man, on voyage from Runcorn to Carrickfergus with coal. Four } \\
\text { survivors. }\end{array}$ \\
\hline
\end{tabular}

The names of the ships have been excluded because of the low numbers fatalities in some cases. SS - steamship; MV - motor vessel; RFA - Royal Fleet Auxiliary; RoRo - roll on roll off; nk - not known 
Table 2. Numbers of seafarers lost and numbers of vessel accidents according to the type of merchant ship and the cargo carried, British merchant shipping, 1925 to 2017, and among British seafarers employed in non-UK ships, 1985-2017

\begin{tabular}{|c|c|c|c|c|c|c|c|c|c|c|}
\hline \multirow[t]{3}{*}{ Type of ship and cargo carried } & \multicolumn{8}{|c|}{ British merchant shipping } & \multirow{2}{*}{\multicolumn{2}{|c|}{$\begin{array}{l}\text { British seafa- } \\
\text { rers employed } \\
\text { in non-UK ships } \\
1985-2017\end{array}$}} \\
\hline & \multicolumn{2}{|c|}{$1925-1938$} & \multicolumn{2}{|c|}{ 1947-1964 } & \multicolumn{2}{|c|}{$1965-1984$} & \multicolumn{2}{|c|}{$1985-2017$} & & \\
\hline & \multicolumn{2}{|c|}{$\begin{array}{l}\text { No. of seafa- } \\
\text { rers lost (No. of } \\
\text { ship accidents) }\end{array}$} & \multicolumn{2}{|c|}{$\begin{array}{l}\text { No. of seafa- } \\
\text { rers lost (No. of } \\
\text { ship accidents) }\end{array}$} & \multicolumn{2}{|c|}{$\begin{array}{l}\text { No. of seafa- } \\
\text { rers lost (No. of } \\
\text { ship accidents) }\end{array}$} & \multicolumn{2}{|c|}{$\begin{array}{l}\text { No. of seafa- } \\
\text { rers lost (No. of } \\
\text { ship accidents) }\end{array}$} & \multicolumn{2}{|c|}{$\begin{array}{l}\text { No. of seafarers } \\
\text { lost (No. of ship } \\
\text { accidents) }\end{array}$} \\
\hline Foundered - coal cargoes & 370 & $(20)$ & 44 & (6) & 16 & (2) & & & & \\
\hline Foundered - metal and ore cargoes & 128 & (9) & 7 & $(1)$ & 60 & $(4)$ & & & 7 & $(2)$ \\
\hline Foundered - grain cargoes & 88 & (6) & 81 & $(4)$ & 9 & $(2)$ & & & & \\
\hline Foundered - timber cargoes & 5 & (1) & 42 & (3) & & & & & & \\
\hline Foundered - stone and cement cargoes & 21 & (3) & 27 & (5) & & & & & 4 & (1) \\
\hline Foundered - ballast & 45 & $(2)$ & 92 & (4) & & & & & 2 & (1) \\
\hline Foundered - other and unknown cargoes & 78 & (5) & 7 & (3) & 20 & (4) & & & 2 & (2) \\
\hline Collisions & 75 & (23) & 83 & $(16)$ & 69 & (3) & & & 3 & $(2)$ \\
\hline Stranded and wrecked & 129 & $(17)$ & 112 & (8) & 22 & $(2)$ & & & & \\
\hline Fires and explosions & 34 & (9) & 152 & (9) & 6 & (3) & 1 & (1) & 1 & (1) \\
\hline Other casualties & 4 & (3) & 10 & (3) & 4 & $(1)$ & & & & \\
\hline \multicolumn{11}{|l|}{ Tankers } \\
\hline Foundered & 107 & (5) & 5 & (1) & 5 & (1) & & & & \\
\hline Collisions & & & 5 & (2) & 24 & (2) & & & & \\
\hline Stranded and wrecked & & & 28 & (2) & & & & & 4 & (1) \\
\hline Fires and explosions & 18 & (7) & 62 & (6) & 46 & (12) & 2 & (1) & 6 & (2) \\
\hline Other casualties & & & 6 & (1) & 1 & (1) & & & & \\
\hline \multicolumn{11}{|l|}{ Passenger ships and ferries } \\
\hline Foundered & 43 & (1) & 9 & (1) & 1 & (1) & 38 & (1) & 6 & (1) \\
\hline Collisions & 8 & (4) & & & 4 & $(1)$ & & & & \\
\hline Stranded and wrecked & 8 & (2) & & & 13 & (1) & & & & \\
\hline Fires and explosions & 5 & (3) & 70 & $(7)$ & 3 & $(1)$ & & & 2 & $(2)$ \\
\hline \multicolumn{11}{|l|}{ Tugs } \\
\hline Collisions and girtings & 22 & (5) & 31 & (8) & 4 & (2) & 9 & (4) & & \\
\hline Other casualties & 36 & (10) & 36 & $(7)$ & 10 & (3) & 1 & (1) & 2 & (2) \\
\hline \multicolumn{11}{|l|}{ Dredgers } \\
\hline Foundered & 22 & $(2)$ & & & 19 & (3) & 4 & $(1)$ & & \\
\hline Other casualties & 8 & $(2)$ & & & 5 & $(1)$ & & & & \\
\hline \multicolumn{11}{|l|}{ Other merchant shipping } \\
\hline Bulk carriers & & & 0 & $(1)$ & 46 & (4) & & & 1 & (1) \\
\hline Schooners and other sailing ships & 35 & (13) & 1 & $(1)$ & & & & & & \\
\hline River barges & 54 & (29) & 10 & (6) & 3 & $(1)$ & & & 1 & (1) \\
\hline Other ships & 1 & (1) & 27 & (4) & 24 & (7) & & & 1 & $(1)$ \\
\hline Total & 1344 & $(182)$ & 947 & $(109)$ & 414 & $(62)$ & 55 & (9) & 42 & $(20)$ \\
\hline
\end{tabular}




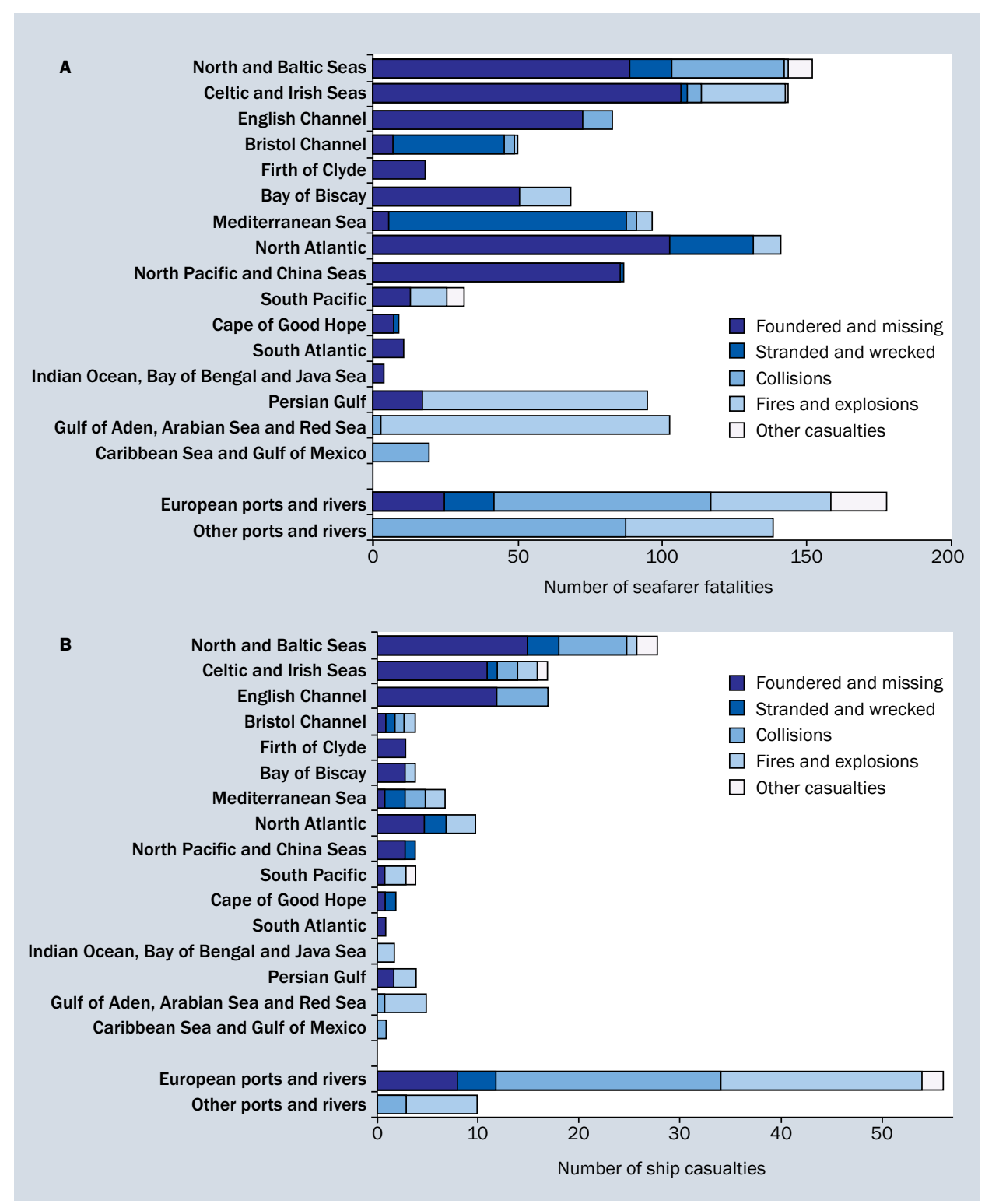

Figure 3. Numbers of seafarer fatalities and ship casualties according to the type and location of the ship casualty, British merchant shipping, 1947 to 2017. A. Seafarer fatalities; B. Ship casualties

(38) while those in tanks largely arose during tank cleaning procedures (22). The 255 fatalities from fires and explosions in other types of ship also occurred mainly in holds (139) which contained explosives (137) or in engine rooms (73).

\section{LOCATION OF CASUALTY AND MONTH OF YEAR}

Most vessel casualties and crew losses occurred in waters around Northern Europe and in European ports and rivers (Fig. 3). The fewer casualties in other regions tended to result in heavier loss of life in individual cases, most notably two disasters during typhoons in the North Pacific (MV Derbyshire and SS Denny Rose, lost with 42 and 37 crew respectively in 1980 and 1967) or amid storms in the North Atlantic (SS Samkey and SS Hopestar,
43 and 40 lost, 1948) and the Bay of Biscay (SS Nordicstar, 34 lost, 1956).

Crew fatalities from wrecked or grounded ships were largely in European ports and rivers, the North Atlantic, the North Sea and the Mediterranean Sea (Fig. 3). Mortality through collisions occurred largely in the North Sea, the English Channel, the River Thames and in ports and rivers generally. Mortality from fires and explosions occurred largely around the Middle East and South Asia, often on major petroleum transport routes including the Red Sea, Persian Gulf and the Arabian Sea (such as SS Indian Enterprise, 72 crew lost in 1950; SS Stanvac Japan, 20 in 1958; MV Dara, 25 crew and 213 passengers, 1962; and SS British Crown, 18, 1966) and also at dock in Britain. They 


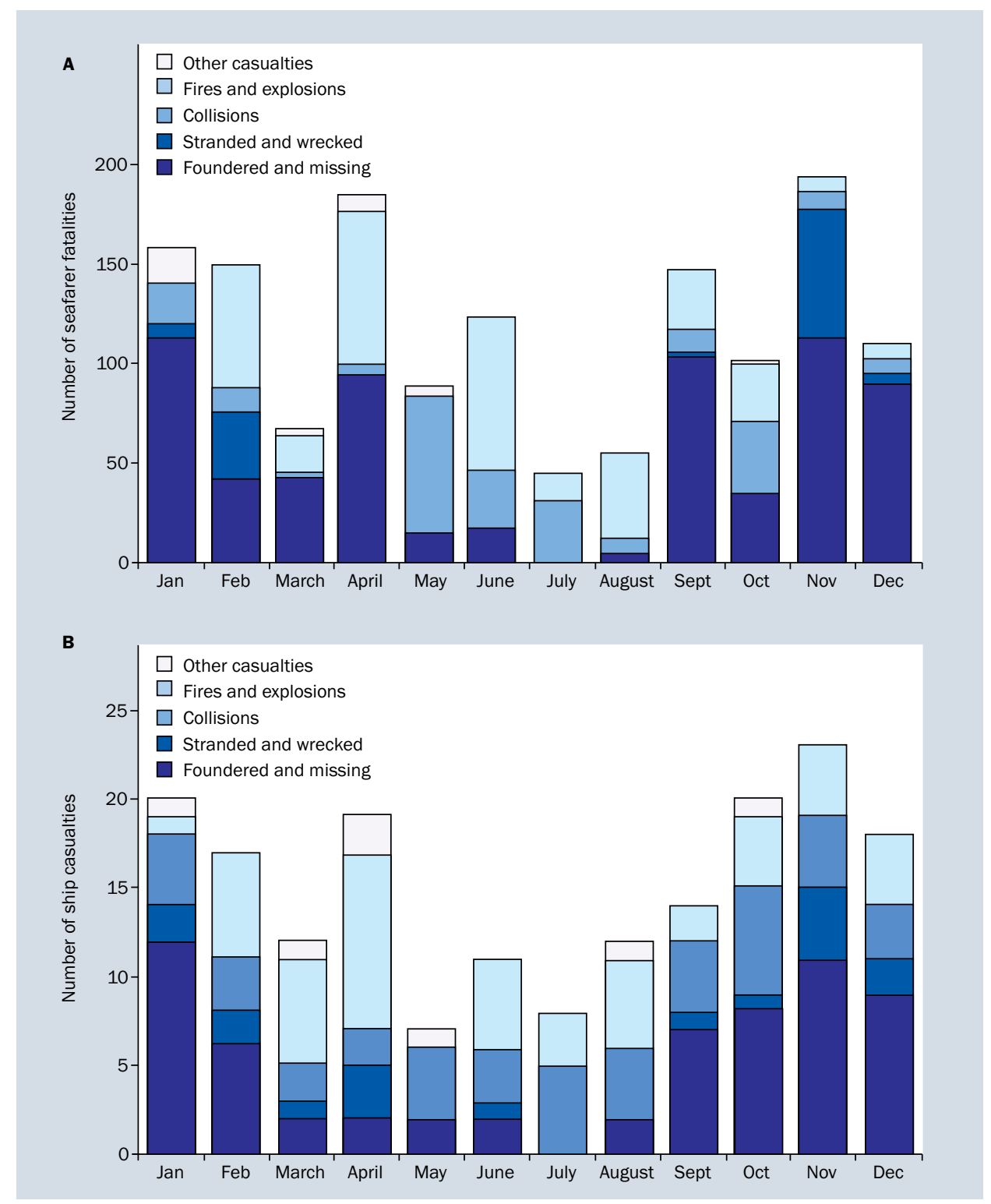

Figure 4. Numbers of seafarer fatalities and ship casualties according to the type of casualty and the month of year, British merchant shipping, 1947 to 2017. A. Seafarer fatalities; B. Ship casualties

were caused largely by explosions involving inflammable cargoes such as oil or explosives, or through smoking on board tankers.

Vessel casualties and crew fatalities both show a strong seasonal pattern, much higher for foundering and wrecked vessels from September to April and largely absent during the summer months (Fig. 4A, B). Collisions are apparent throughout the year but fires and explosions in merchant shipping are less frequent during winter and colder months.

\section{DISCUSSION}

The study is based on reviews of a range of different casualty information sources in order to establish the causes and circumstances of ship casualties in a merchant fleet over a 92 year period. Through using different information sources, the coverage of all vessel casualties and crew fatalities is strong. Nonetheless, with some of the information sources restricted to the last 30 to 55 years, coverage is better in later than in earlier years of the 92 year study period. Despite extensive reviews and searches, coverage is also likely to be better for accidents involving larger merchant ships than for small vessels such as sailing ketches, river barges and tugs. It would also be more complete for ships that were major casualties or 'total losses', through foundering, wrecks or disappearances, rather than for ships with less severe damages that were repaired and returned to service, for example, through less extensive fires, collisions, stranding or beaching. 
Over the 92 years, there have been large, consistent reductions in both ship casualties and crew fatalities. In this study it has not been practicable to assess casualty rates for different type of ship in terms of ship-years, as the numbers of ships by type are not available over the long study period consistently in detail. This will be assessed further in future when looking at specific questions raised by this investigation. The reductions have been apparent in almost all sectors of merchant shipping, but have been greatest for vessels that were stranded or wrecked or were involved in collisions, particularly those involving small coastal trading cargo ships. These reductions can be attributed largely to major developments and improvements over time in ship navigational aids. Other contributory factors include improvements over time in ship designs and rescue services and also reductions in the volume of small coastal trading ships.

The large reductions in ship accidents and crew fatalities since the 1980s have coincided with an increasing proportion of accidents and fatalities among British seafarers employed in open register and other non-UK shipping [21]. The current study shows that since 1985 , there have been more than twice as many ship casualties, with fatalities to British seafarers, in non-UK ships as in the British fleet itself. This may partly reflect that cargo-carrying ships were more often flagged out than passenger ships and dredgers, which tend to have lower risks of (cargo-related) casualties and crew losses. However, especially as some of the disasters in open register shipping occurred in controversial circumstances $[13,18,19]$ it also suggests that some substandard shipping has been flagged out or that lower cost but less competent crews have been employed, perhaps to bypass more rigorous safety standards.

Inquiries revealed that most of the coastal trading cargo ships that foundered were caused by cargo shifts, usually in gales or adverse weather conditions. Grain and coal cargoes are regarded as two of the most hazardous in terms of susceptibility to shifting. They accounted for more than one half of the cargoes carried by coasters that foundered through cargo shifts in this study. Other cargoes that shifted and led to coasters foundering were stone chippings, also somewhat prone to shifting, and iron and steel, which are among the most dense of cargoes and are more commonly associated with the foundering of bulk carriers, mainly through stresses placed on hulls at sea as well as structural damages when unloading cargoes in port [22, 23]. Although few fatal cargo shifts were identified in larger deep sea trading ships in our study, cargo shifts remain a major problem in bulk shipping as well as in coasters. In particular, there has been a recent increase in bulk carrier fatalities globally that has been due partly to the liquefaction and shifting of nickel ore cargoes [24].
Reductions in ship casualties and crew fatalities have been greater in dry cargo shipping than in other sectors such as tankers and tugs. For tugs, although there have been large reductions in casualties and crew fatalities through foundering and wrecking, more specific casualties involving fatal girtings and collisions with the ships that the tugs were towing have persisted in recent years and continue to be a problem [25].

The study shows a strong seasonal pattern in the occurrences of ship casualties and crew fatalities according to the type of casualty. Losses through ships that foundered, disappeared or wrecked were much higher during winter months and also September but largely absent during the summer. The most severe typhoons globally occur in the North West Pacific region, often around September [26], and 2 ships in this study disappeared during North West Pacific typhoons at this time with the combined loss of 79 crew and 2 passengers. As many of the casualties occurred during storms and gales as well as typhoons, this suggests that some losses could have been prevented if greater caution had been exercised following hazardous shipping forecasts. Crew losses from fires and explosions occurred largely outside home waters and during warmer months, but this largely reflects the trades and flammable cargoes carried rather than any seasonal effects. Losses through collisions occurred throughout the year, including the summer months when the volume of small-scale shipping and sailing increases. Crew fatalities through collisions were highest in the North Sea (largely involving coal trading coasters), the River Thames (various ships, sailing vessels, barges and tugs) and the English Channel. These waters have some of the most busy sea lanes and have previously been studied in detail [27-29].

\section{CONCLUSIONS}

1. There have been large reductions in both ship casualty and crew fatality rates in British shipping. These have been greatest for vessels that were stranded, wrecked or foundered, particularly involving small coastal trading cargo ships.

2. There were strong seasonal and geographical patterns, with most fatalities through foundering or wrecking occurring during winter months around Europe.

3. Reductions since the 1980 s have coincided with proportionate increases in ship accidents and crew fatalities involving British seafarers employed in 'open register' shipping.

4. Some disasters in open registry shipping occurred in controversial circumstances, suggesting that some substandard shipping has been flagged out or that lower cost but less competent crews have been employed, perhaps to bypass more rigorous safety standards. 
5. Reductions in ship casualties and crew fatalities reflect major developments and improvements in ship navigational aids, improvements in rescue services and ship designs, and reductions in the volume of small coastal trading ships.

\section{ACKNOWLEDGEMENTS}

The authors are grateful to Cathy Pennock and the Marine Accident Investigation Branch for helpful advice, provision of accident investigation files and for help with tracing fatalities in non-UK shipping. Thanks also to John Crilley, previously of Lloyd's Register, for advice and help with Lloyd's casualty data and to the Registry of Shipping and Seamen for providing access to death inquiry files and death registers.

\section{REFERENCES}

1. Royal Commission on Loss of Life at Sea. First report of the Royal Commission on Loss of Life at Sea with minutes of evidence. London: Eyre and Spottiswoode. 1885.

2. Home WE. Mortality of British merchant seamen. Lancet. 1934; 223(5777): 1081-1083, doi: 10.1016/s0140-6736(00)94094-7.

3. Otterland AA. Sociomedical study of the mortality in merchant seafarers. Gotebörg: Scandinavian University Books. 1960.

4. Lloyd's Register of Shipping. Casualty returns, 1963-2010. London: Lloyd's Register of Shipping. 1964-2011.

5. Lloyd's Register of Shipping. World Fleet Statistics, 1963-2010. London: Lloyd's Register of Shipping. 1964-2011.

6. Board of Trade. Return of shipping casualties and deaths. Vessels registered in the United Kingdom [annual returns for 1925-38]. London: HMSO. 1926-1939.

7. Ministry of Transport. Return of shipping casualties and deaths: vessels registered in the United Kingdom. [annual returns for 1948-63 with summary tables for the years 1939-47]. London: HMSO. 1949-1964.

8. Board of Trade. Shipping casualties and deaths. Vessels registered in the United Kingdom [annual returns for 1964-68]. London: HMSO. 1965-1969.

9. Department of Trade and Industry/Department of Industry/Department of Trade/Department of Transport. Shipping casualties and deaths. Vessels registered in the United Kingdom [annual returns for 1969-88]. London: HMSO. 1970-1989.

10. Marine Accident Investigation Branch. Annual reports, 1989-2017. Southampton: Marine Accident Investigation Branch. 1990-2018.

11. Maritime and Coastguard Agency. Crewing estimates based on Maritime and Coastguard Agency survey data. (information provided on request).
12. Lloyd's Register of Shipping. Casualty data, 1980-2005 (casualty data from Lloyd's).

13. Hooke, N. Maritime Casualties 1963-1996. London: Lloyd's Maritime Information Services. 1997.

14. Wrecksite EU. www.wrecksite.eu.

15. British Newspapers Archive. www.britishnewspaperarchive.co.uk.

16. Department of Transport. MV Herald of Free Enterprise: Report of Court No. 8074. London: HMSO. 1987.

17. Department of the Environment, Transport and the Regions. M.V. Derbyshire Surveys: UK/EC Assessors' Report. London: Department of the Environment, Transport and the Regions. 1998.

18. Hansard. House of Commons Debates 28th June 1973, vol 858 cc405-7W. http://hansard.millbanksystems.com/written_answers/1973/jun/28/royston-grange.

19. Hansard. House of Commons Debates 27th March 1990 vol 170 cc460-8. www:hansard.millbanksystems.com/commons/1990/ mar/27/m-v-marine.

20. Marine Accident Investigation Branch. Flooding and sinking of dry cargo vessel Rema with loss of 4 lives. Southampton: Marine Accident Investigation Branch. 2000.

21. Roberts SE. Work-related mortality among British seafarers employed in flags of convenience shipping, 1976-95. Int Marit Health. 2003; 54(1-4): 7-25, indexed in Pubmed: 14974774.

22. International Association of Classification Societies. Guidance and Information on Bulk Cargo Loading and Discharging to Reduce the Likelihood of Over-stressing the Hull Structure. London: International Association of Classification Societies. 1997.

23. Bureau of Transport and Communications Economics, Structural failure of large bulk ships, Report 85. Canberra: Australian Government Publishing Service. 1994.

24. International Association of Dry Cargo Shipowners (INTERCARGO). Benchmarking Bulk Carriers. London: International Association of Dry Cargo Shipowners. 2011.

25. West of England $P$ \& I. Loss Prevention Bulletin: The Risk of Tugs Capsizing due to Girting. www.westpandi.com/globalassets/ loss-prevention/loss-prevention-bulletins/west-of-england-pandi--the-risk-of-tugs-capsizing-due-to-girting.pdf.

26. Landsea CW. Climate Variability of Tropical Cyclones: Past, Present and Future. In: Storms (volume 1). New York: Routledge. 2000.

27. Hargreaves ER. Safety of navigation in the English Channel. J Navigation. 1973; 4: 399-407.

28. Dare SC, Lewison G. The recent casualty record in the Dover Strait. J Navigation. 2009; 33(02): 192-205, doi: 10.1017/ s0373463300035207.

29. Squire D. The Hazards of Navigating The Dover Strait (Pas-de-Calais) Traffic Separation Scheme. J Navigation. 2003; 56(2): 195-210, doi: $10.1017 /$ s0373463303002182. 